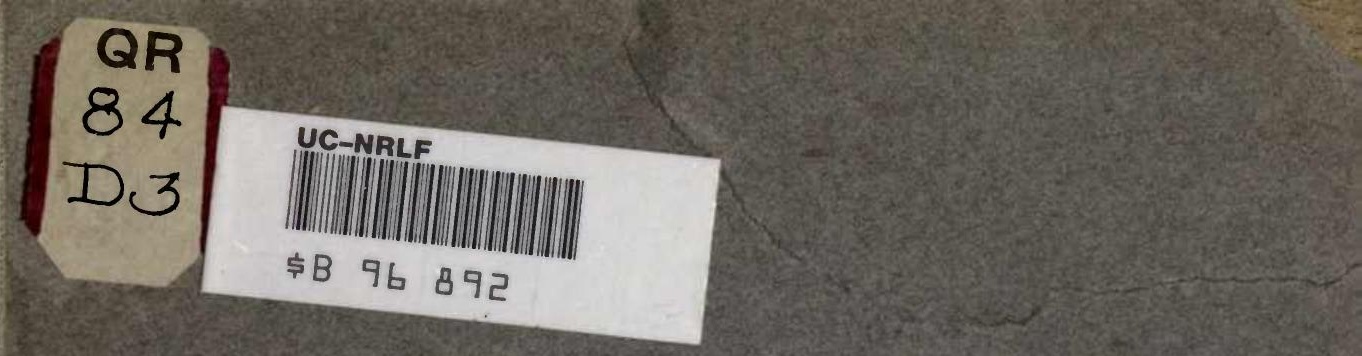



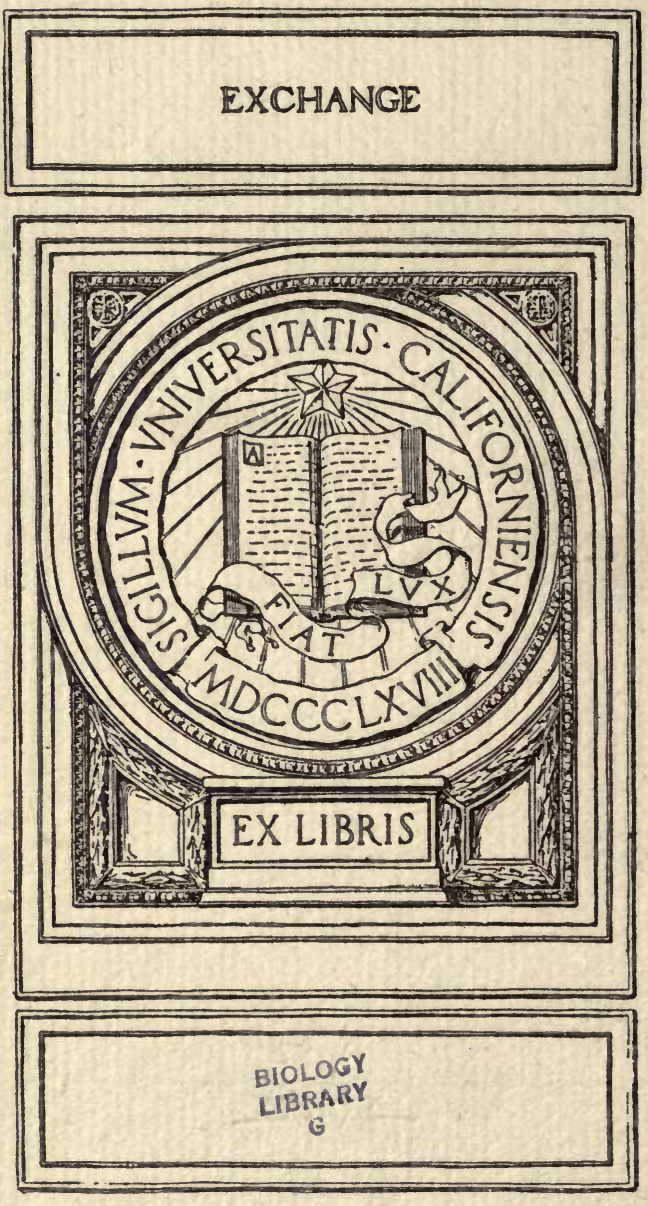



\section{Variations in Bacteria Caused by Change of Medium}

Submitted in partial fulfillment of the requirements for the degree of Doctor of Philosophy, in the Faculty of Pure Science, Columbia University

$$
\text { By }
$$

ANDREW IgNatius Dawson

I 9 I 8 


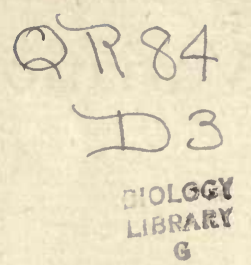

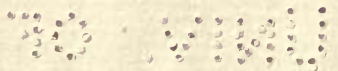

$$
\begin{aligned}
& \therefore: \because \because \cdots \vdots
\end{aligned}
$$




\section{TABLE OF CONTENTS}

Introduction

Procedure; preliminary . . . . . . . . 2

Determination of water content of bacteria (Table I) . . . 4

Biochemical constituents . . . . . . . . . 5

Procedures; special . . . . . . . . . . 5

Media employed in analyses (Table II) . $\quad$. $\quad . \quad$. 99

Special data pertaining to analyses (Table III) . . . IO-II

Summary of results (Table IV) . . . . . . . 12

Fermentation of carbohydrates (Table V) . . . . . 13

Agglutination results (Table VI) . . . . . . . ${ }^{\text {I }} 4$

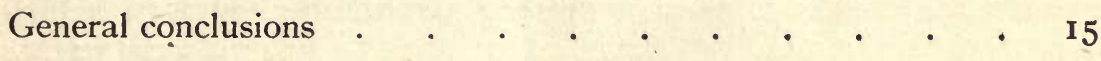




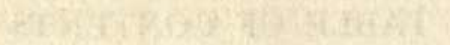

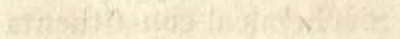




\section{VARIATIONS IN BACTERIA CAUSED BY CHANGE OF MEDIUM}

INTRODUCTION

It is to be regretted that the tendency of investigation in bacteriology has been largely a study of effects, with little or no attempt to explain their fundamental causes. This is probably because the latter problems involve greater technical difficulties and offer less hope of immediate solution. Until a definite scientific foundation has been built up, however, on which to correlate the numberless already known facts, these will always remain isolated and to some extent unexplainable.

Bacteria, like all living cells, produce changes in internal composition as well as in external environment by means of chemical reactions. Living protoplasm, in order to maintain its viability, is constantly abstracting certain essentials from its environment, and replacing them by other substances, while it is itself in a constant state of alteration.

The changes wrought in the surrounding material by the presence of bacteria can only be definitely, that is chemically, followed by cultivating them upon media of known and exactly reproducible composition, the so-called synthetic media. Suitable media of this type are not easily developed, but work is in progress along this line which cannot fail to bring to light many significant and fundamental relationships.

Changes within the bacterial bodies are even harder, if not entirely impossible, to follow completely. The present means which analytical chemists have at their disposal in the investigation of the most complicated of all known forms of matter are palpably imperfect. Bacterial changes, however, may be at times accompanied by (I) alterations in the empirical chemical composition of the whole bacterial bodies, and (2) alterations in the biological behavior of the organisms. Alterations in both these quanta are demonstrable, and can, at least in part, be correlated with their etiological factors.

In this paper we have attempted to add something to the data regarding the extent of alteration in the empirical composition of bacteria, to show how such alterations may be brought about, and to 
draw certain conclusions regarding their probable causes. We hope that at least the data here presented will be useful to future investigators of this field.

To produce a determinable change in either the properties or composition of bacteria, it is necessary to change their environment. This is easily done by first altering the nature of the medium upon which they are grown. By regulating the transplants with sufficient frequency to make sure that the changes observed are not due to bacterial 'old age', and by continuing cultivation on the altered medium long enough to produce a reasonably complete adaptation of the organism to its new environment, the experiments can be adequately controlled, and an observable change of properties and composition, if such is possible, can be obtained.

The determination of the chemical composition of bacterial bodies is not an easy task. Ordinary bacterial growths are actually composed of very small quantities of material, and the production of sufficient bacterial substance for a chemical analysis is difficult.

\section{PRELIMINARY PROCEDURE}

In order to determine the biological change in bacteria in any direction, it is necessary ( 1 ) to preserve the same organism throughout all determinations, and (2) to determine the total activity of the organism in statu quo as far as possible, and (3) lastly, to subject the organism to constant varied conditions.

In accordance with these requirements, a strain of B. Coli, which showed ready and abundant growth, was selected and preserved in all the following operations. It had been previously cultured on meat-extract agar for an unknown number of generations, of which at least 250 are known. In regard to this culture two questions present themselves: Old Age and Adaptation. If the organism is in a state of decrepitude, a transfer to other medium may mean only rejuvenation, which could assert itself in the next generation on different medium on which the organism could have the widest scope for metabolic processes. A tentative verification of this proceeded as follows: A twenty-four hour culture of the organism was emulsified in sterile salt solution of which a measured volume was plated on two different media: meat-extract agar, and meat-infusion-dextrose agar. After twenty-four hours' incubation the former showed 75 colonies, the latter showed 63 . There seemed to be no distinguishing 
characteristic in the organism or in the colonies of the two plates. In this experiment enough evidence is presented to assume that the question of old age in this strain may be considered as eliminated.

The laws of adaptation, on the other hand, govern the internal state of the organism in its present conditions either fully or only partially. If the organism is fully habituated to its environment, a substantial change of environment effects a growth which is sparse; or, really or apparently abundant; or, no growth at all. If the abundant growth is apparent, and not real, it will be transitory; if real, it will persist.

Whether bacteria obey the laws of adaptation fully, partially, or not at all, may or may not be proven by external phenomena; but since the question should receive some answer from an examination of internal protoplasmic conditions, a priori an organism confined to one environment for many generations ought to offer help to this end. The exact number of generations that will influence bacteria in this direction has not been determined. Arbitrarily, therefore, the 20oth generation was chosen to initiate the solution of the question. In all the following experiments the organism has been confined to one medium for at least 200 generations before it was finally grown on this medium for examination.

In order to determine the biological activity of the organism in its present environment, it was cultured on medium to which it had been accustomed, i.e., agar, 2.5 per cent; peptone, r.o per cent; $\mathrm{NaCl}$, 0.5 per cent; meat-extract, I.O per cent; incubated in test tubes $8 \mathrm{x} \mathrm{I}$ inch at $37^{\circ} \mathrm{C}$. Under these conditions growth after 24 hours was fairly abundant, and even seemed to increase after that period.

To prove approximately an increase or decrease in growth after 24 hours' incubation, Ioo tubes of different ages were selected, the planted area of which seemed to be of the same dimension. The growth was scraped from the medium at 24 -hour intervals, transferred to weighing bottles, and weighed. After weighing, the material was carefully preserved at $0^{\circ}$ to $5^{\circ} \mathrm{C}$. for further examination.

Growth of 9 to II days proved to be the maximum.

In as much as the presence of moisture affects the weight of the collected bacteria, it is necessary to determine what relation moisture bears to the organism. This determination will decide whether, and to what degree, the growth has been increased really or only apparently. Determinations, therefore, of the water content were made by drying 
the collected organism in weighing bottles at $97^{\circ} \mathrm{C}$. over calcium chloride to constant weight, which required seven days, and cooling the dried material in vacuo over the same dryer. Experiments in this direction indicate that what holds true for bacterial derived substances (Leach, Journal of Biological Chemistry, 1906, 1, 463), also holds true for the whole bacterium, e.g., that bacteria show a great

TABLE I

\begin{tabular}{|c|c|c|c|c|c|c|c|}
\hline \multirow{2}{*}{$\begin{array}{l}\text { Days' } \\
\text { Growth }\end{array}$} & \multicolumn{3}{|c|}{$\begin{array}{c}\text { Approximate Rate of Bacterial } \\
\text { Growth in Ioo Tubes }\end{array}$} & \multicolumn{3}{|c|}{$\begin{array}{c}\text { Approximate Weight of Bacteria } \\
\text { after Desiccation }\end{array}$} & \multirow{2}{*}{$\begin{array}{c}\text { Approximate } \\
\text { Average } \\
\text { Per Cent. } \\
\text { Loss by } \\
\text { Desiccation }\end{array}$} \\
\hline & $I$ & $I I$ & $I I I$ & $I$ & $I I$ & $I I I$ & \\
\hline I & 2. & I. 7 & 2.3 & .05 & .05 & .07 & 97 \\
\hline 2 & $2 . I$ & 1.9 & 2.4 & .06 & .06 & .07 & 97 \\
\hline 3 & 2.1 & 2.0 & 2.5 & .10 & .10 & .13 & 95 \\
\hline 4 & 2.7 & 2.4 & 2.7 & .25 & .24 & .28 & 90 \\
\hline 5 & 3.2 & 2.7 & $3 \cdot 3$ & .54 & .47 & .56 & 83 \\
\hline 6 & 3.2 & 3.0 & 3.6 & .54 & $.5 \mathrm{I}$ & .60 & 83 \\
\hline 7 & $5 \cdot 3$ & 3.7 & 4.5 & .90 & .63 & .77 & 83 \\
\hline 8 & 5.9 & 3.9 & 5.8 & I. 30 & .86 & I. 30 & 78 \\
\hline 9 & 5.9 & 4.5 & 6.3 & I. 30 & 1.00 & 1.40 & 78 \\
\hline IO & 6.2 & 4.6 & $\cdot 6.5$ & 1.60 & 1.20 & 1.80 & 74 \\
\hline I I & 6.5 & 4.6 & 6.8 & 1.70 & 1.20 & 1.80 & 74 \\
\hline 12 & 6.3 & 4.6 & 6.8 & 1.70 & 1.20 & 1.80 & 73 \\
\hline 13 & 6.3 & 4.4 & 6.8 & 1.70 & 1.20 & 1.80 & 73 \\
\hline 14 & 6.0 & 4.2 & 6.7 & 1.70 & 1.20 & 1.80 & 72 \\
\hline
\end{tabular}

avidity for water. The water content of bacteria, therefore, seems to be subject to variations dependent on the time extent of incubation. The variation does not seem to depend on mere mechanical adhesion, because: (I) of the difficulty attendant on desiccation; (2) of the power of absorbing moisture which dried bacteria or bacterial substances display to such an extent that three days' exposure to ordinarily dry atmosphere increases the weight of the desiccated material 0.05 per cent.

It may not be contended that the entire loss of weight by desiccation is due to water alone, since bacteria may contain volatile 
substances. The fact of loss of weight keeping pace with the age of the culture may be interpreted to mean that the organism in an environment of abundant food may need more than the ordinary supply of water, so that, the food decreasing, there is a decrease in the amount of water absorbed.

\section{CULTURAL CHARACTERISTICS}

Since the characteristics of the organism as grown on its accustomed medium are to be compared with those of a changed environment, a summary of the present characteristics is necessary. In morphology, staining, and cultural traits, this organism showed only what is ordinary to B. Coli. On Hiss' carbohydrate-serum-water medium, it produced acid and gas in dextrose, levulose, galactose, maltose, saccharose, dextrin, and mannit.

\section{BIOCHEMICAL CONSTITUENTS}

Preliminary. The biochemical constituents are here understood as Water and Volatile Matter; Ash and Ash Constituents; Sulphur; Phosphorus; Calcium; Total Nitrogen; Amino-Nitrogen; Fats and Waxes; Coagulable Protein; Soluble Protein; Carbohydrates; Cellulose-like Substances; Residue.

In making determinations of this nature on bacteria, some of the well established methods are obviously inapplicable, and less well recognized ones had to be adopted, e.g., extraction of fat. This necessitated, in such cases, before all else a careful investigation of the method.

\section{DISCUSSION OF METHODS}

Water and Volatile Matter were determined only by desiccation.

AsH. The material was incinerated in a silica crucible and kept at a dull red glow to constant weight; cooled in vacuo and weighed. Constituents of Ash were subjected to ordinary qualitative and quantitative methods.

SUlPhur. Total Sulphur was estimated on both wet and dried bacteria. The material was heated with sodium carbonate and an excess of potassium nitrate, extracted with water, neutralized, and after precipitation weighed as barium sulphate. 
Loosely Combined Sulphur was estimated as sulphide. The material was boiled 4 hours in 10 per cent. $\mathrm{KOH}$, neutralized with acetic acid, and precipitated as lead sulphide, care being taken during the process to prevent the formation of lead sulphate or carbonate.

Phosphorus. The material was first decomposed by boiling nitric acid precipitated by ammonium-phospho-molybdate, redissolved in ammonium hydroxide, reprecipitated and estimated as magnesium pyrophosphate.

Calcium. The material was decomposed by boiling sulphuric acid, precipitated by absolute alcohol, washed with 40 . per cent alcohol at $34^{\circ} \mathrm{C}$., and weighed as sulphate.

Total Nitrogen. This was estimated by the macro-Kjeldahl method. Amino-Nitrogen was determined by the Van Slyke method.

\section{Coagulable Protein}

Preliminary. Since a quantitative estimation of the protein content of the bacterial cell would assist in determining biological variations, the ideal method of protein extraction would involve the disintegration of the cell material without injury to the proteins. But the cellulose-like structure of the cell presents interference. To dissipate this, two alternatives are offered: to employ a cellulose enzyme, or to carry on extraction as far as possible by means of chemical reagents. Enzymes, however, are objectionable. Chemical reagents, therefore, must be resorted to, success depending on proper selection.

In exploring the effect of acids, alkalis, and neutral salts and solvents on proteins, it appeared that distilled water and sodium chloride possess greatest efficiency especially at reduced pressure. Of the two solvents distilled water was discarded because it extracted fats together with proteins; sodium chloride was selected as being a more powerful protein solvent.

The method of determining quantitatively the protein content of bacteria was therefore the following: Weighed amounts of wet bacteria were subjected to extraction by a definite amount of 6 . per cent $\mathrm{NaCl}$ for 24 hours at $50^{\circ} \mathrm{C}$., under $250 \mathrm{~mm}$. pressure. After sedimentation, decantation of the supernatant liquid followed. The sediment was washed, and after the wash waters had been added to the original liquid, the whole was reduced to its original volume by evapo- 
ration. Part of this solution was weighed to ascertain the approximate protein content.

This solution heated to $85^{\circ}$ to $90^{\circ} \mathrm{C}$., with enough acetic acid to concentration of 0.0 I per cent, produces a coagulum, which when washed and dried on a weighed filter, is estimated as coagulable protein. The filtrate from the previous operation, after being diluted to o.I per cent $\mathrm{NaCl}$ and divided into two parts; one part having been precipitated by $\mathrm{HCl}$ o. I per cent, and the other part by 0. I per cent $\mathrm{KOH}$. The precipitates were washed, dried, and weighed as acid-precipitable and alkali-precipitable protein.

The filtrates from the acid- and alkali-precipitations still gave evidence of containing protein not easily precipitated by mineral acids, alkalis, and neutral reagents. After neutralizing, the protein content of these filtrates was estimated by Esbach's method and listed as soluble proteins.

The insoluble residue containing a protein which resisted extraction, was subjected to tryptic digestion; the difference in weight before and after digestion was recorded as insoluble protein.

The substance remaining after the last operation, having given no protein reaction, nor showing the presence of nitrogen, was reserved for other examinations as residue.

\section{FATS}

Preliminary. Determinations of fat could not be done with accuracy until the known methods were examined. Experiments showed fat to be at least partly intracellular, and consequently total disintegration of the cell necessary. The liberation of fat without its deterioration after cell disintegration was effected by means of alkaline hypochlorite, commercially known as 'antiformin'.

Method. Weighed quantities of wet bacteria were treated with 20. per cent antiformin for 24 hours at $30^{\circ} \mathrm{C}$., then warmed to $60^{\circ} \mathrm{C}$., for one hour. After cooling to $15^{\circ} \mathrm{C}$., and neutralizing with $\mathrm{N} /$ Io sulphuric acid, it was evaporated to dryness at $80^{\circ} \mathrm{C}$., ground, and extracted with ethyl- or petrol-ether.

This residue was slowly boiled in 10 . per cent $\mathrm{NaOH}$, and after boiling was rendered acid with dilute sulphuric. It was then diluted to three times the original volume with distilled water and cooled to $7^{\circ}$ to $10^{\circ} \mathrm{C}$., after which it was filtered. The precipitate was washed, dried, and extracted for five hours with petrol-ether. 


\section{CARBOHYDRATES}

Preliminary. When the bacterial residue, after protein extraction, is treated with concentrated sulphuric acid at ordinary temperature, it becomes turbid, dark-brown, finally turning to clear deep-red. If this reaction is hastened by gentle heat to $40^{\circ}$ to $45^{\circ} \mathrm{C}$., for one hour, diluted with 5 . per cent $\mathrm{KOH}$, then neutralized, the solution gives reaction for reducing substances.

If the same process be carried on at a lower temperature, the activity of the acid is decreased, as is evidenced by the color, but the amount of reducing substance seems to increase. Also, whether normal bacteria or bacterial residue be employed in this process, it happens that when the reaction has proceeded to the production of a deep-red coloration without turbidity, if cold distilled water be slowly added, a heavy gelatinous precipitate settles out of the solution. After neutralizing, this solution may be filtered and the precipitate recovered. The amount of reducing substances under these conditions is reported as carbohydrate in terms of glucose.

The precipitate here obtained, after being washed by decantation, was found to yield a brown color with iodine, and not to be colored blue by iodine-zinc chloride. It is soluble in ammoniacal cupric oxide (Schweitzer's reagent); reprecipitated by acids, is soluble in zinc chloride, from which it can be recovered on dilution with water. On hydrolysis with sulphuric acid reducing substances are formed.

These characteristics are essentially those of cellulose, and we regard the material so obtained as similar to, if not identical to, that substance. The presence of cellulose in bacterial bodies has been a much discussed question as throwing possible light on the vegetable nature of bacteria. The findings of Vaughan (Protein Split Prod. pp. 66,67 ) seem to indicate that cellulose is absent in bacteria, but we are inclined to consider our results as confirming those of Dreyfuss, Hammerschlag, and others (Zeitschrift für physiologische Chemie, I887, ix, I8I).

The precipitate here obtained and quantitatively estimated by collecting it on a weighed filter and weighing was, therefore, reported as cellulose-like substance.

Determinations. After experimental examination, the above methods were adopted uniformly and without modification.

The material for these determinations was a nine days' growth of B. Coli, collected at the stage of maximum development. 
The media employed for obtaining growth and representing change of environment are described in the adjoined table.

TABLE II

MEDIA EMPLOYED IN OBTAINING NINE DAYS' GROWTH OF B. COLI FOR ANALYSES

SOLID MEDIA: VEHICLE, AGAR 2. PER CENT

Titration

Neutral

I. Peptone, I. per cent Meat extract, I.O per cent

Alkaline

II. Peptone, 0.5 per cent

Edestin, 0.5 per cent

Alkaline

III. Peptone, 0.25 per cent

Flour proteins, 1.o per cent

IV. Peptone, 0.25 per cent

Meat extract, I.o per cent; Glucose, 1.0 per cent

Neutral

V. Peptone, 0.25 per cent

Meat extract, I.o per cent; Glucose, I.o per cent.; Glycerol, I.O per cent

Neutral

VI. Peptone, 0.25 per cent

Butter soap, I.o per cent

VII. Peptone, 0.25 per cent

Butter soap, 1.o per cent

VIII. Peptone, none

Potato juice, from whole unskinned potato, freed from starch; 500 grams potato to litre of medium

Bacteria collected from these several media constitute the material for analyses by the methods already indicated, the number of determinations in each analysis varying from 7 for ash to 20 for nitrogen. For the sake of brevity three of the most variant results are indicated in Table III.

Since Table III does not include the results of all determinations, but only the most variant, for the purpose of comparison the average result for each series of determinations is therefore appended. Table IV presents variations in almost all bacterial constituents. Though strict interpretation of these results must necessarily await the light of further research, attention must be directed to the fact that from the simplest to the complex constituent variation is evident. The water content varies, which may not be as significant as other variations. There is an increase in the amount of ash and amino-nitrogen in the case of fat-media; protein is high where protein is present in the medium, and highest where the medium-protein is in soluble form. 
TABLE III

Data pertaining to the analyses of $B$. Coli

grown on Media I to VIII

Determinations and calculations are based on Wet Bacteria

\begin{tabular}{|c|c|c|c|c|c|c|c|c|}
\hline & \multicolumn{8}{|c|}{ MEDIUM } \\
\hline & $\begin{array}{c}I \\
\text { Per } \\
\text { Cent. }\end{array}$ & $\begin{array}{c}\text { II } \\
\text { Per } \\
\text { Cent. }\end{array}$ & $\begin{array}{c}\text { III } \\
\text { Per } \\
\text { Cent. }\end{array}$ & $\begin{array}{c}\text { IV } \\
\text { Per } \\
\text { Cent. }\end{array}$ & $\begin{array}{c}V \\
\text { Per } \\
\text { Cent. }\end{array}$ & $\begin{array}{c}\text { VI } \\
\text { Per } \\
\text { Cent. }\end{array}$ & $\begin{array}{c}\text { VII } \\
\text { Per } \\
\text { Cent. }\end{array}$ & $\begin{array}{c}\text { VIII } \\
\text { Per } \\
\text { Cent. }\end{array}$ \\
\hline \multirow{3}{*}{$\begin{array}{l}\text { Water and Volatile } \\
\text { Matter }\end{array}$} & 74.45 & $72.5^{2}$ & 60.28 & 75.10 & 75.00 & 60.70 & 60.36 & 79.62 \\
\hline & 74.83 & 72.50 & 60.22 & 75.08 & 74.83 & 60.66 & 60.31 & 79.56 \\
\hline & 74.86 & 72.43 & 60.20 & 75.00 & 74.96 & 60.60 & 60.26 & 79.50 \\
\hline \multirow[t]{3}{*}{ Ash } & 4.80 & 2.73 & 2.53 & $4 \cdot 5 \mathrm{I}$ & $4 \cdot 50$ & 7.84 & 7.69 & 2.14 \\
\hline & 4.80 & 2.70 & 2.50 & $4 \cdot 5^{I}$ & $4 \cdot 50$ & 7.83 & 7.69 & 2.11 \\
\hline & 4.80 & 2.69 & 2.44 & $4 \cdot 49$ & $4 \cdot 50$ & 7.83 & 7.67 & 2.03 \\
\hline \multirow[t]{3}{*}{ Sulphur (Total) } & 0.06 & & & O.I I & 0.10 & & & 0.16 \\
\hline & 0.05 & & & 0.09 & 0.10 & & & 0.14 \\
\hline & 0.05 & & & 0.08 & 0.09 & & & 0.11 \\
\hline \multirow{3}{*}{$\begin{array}{l}\text { Sulphur (Loosely Com- } \\
\text { bined) }\end{array}$} & & & & 0.02 & 0.01 & & & 0.03 \\
\hline & & & & 0.01 & 0.01 & & & 0.03 \\
\hline & & & & 0.01 & 0.01 & & & 0.02 \\
\hline \multirow[t]{3}{*}{ Phosphorus (as $\mathrm{P}_{2} \mathrm{O}_{5}$ ) } & 4.25 & 3.50 & 2.38 & 2.90 & 3.31 & $1.7 \mathrm{I}$ & I. 83 & 0.92 \\
\hline & 4.25 & 3.48 & $2.3^{8}$ & 2.88 & 3.29 & 1.69 & 1.83 & 0.92 \\
\hline & 4.22 & 3.47 & 2.37 & 2.87 & 3.28 & 1.69 & 1.83 & 0.92 \\
\hline \multirow[t]{3}{*}{ Calcium (as $\mathrm{CaO}$ ) } & 2.71 & 0.05 & 1.07 & 2.62 & $2.6 \mathrm{I}$ & 2.34 & 2.35 & 0.19 \\
\hline & 2.67 & 0.05 & 1.06 & 2.62 & 2.60 & 2.33 & 2.33 & 0.18 \\
\hline & 2.63 & 0.04 & 1.06 & $2.6 \mathrm{I}$ & 2.59 & 2.34 & 2.33 & 0.18 \\
\hline \multirow[t]{3}{*}{ Nitrogen (Total) } & 2.844 & 3.009 & 6.227 & 2.419 & 2.120 & 4.330 & 5.012 & 5.030 \\
\hline & 2.842 & 3.012 & 6.222 & 2.410 & 2.113 & 4.330 & 5.009 & 5.026 \\
\hline & $2.84 \mathrm{I}$ & 3.022 & 6.219 & 2.400 & 2.109 & 4.328 & 5.003 & 5.023 \\
\hline \multirow[t]{3}{*}{ Nitrogen (Amino-) } & 0.780 & 0.930 & 2.976 & 0.730 & 0.693 & 1.721 & $\mathrm{I} .65 \mathrm{I}$ & 3.016 \\
\hline & 0.777 & 0.887 & 2.969 & $0.72 \mathrm{I}$ & 0.690 & $\mathbf{1} .689$ & 1.650 & 3.011 \\
\hline & 0.774 & 0.874 & 2.968 & 0.718 & 0.687 & I. 659 & 1.650 & 3.007 \\
\hline \multirow[t]{3}{*}{ Protein (Coagulable) } & 2.99 & 1.00 & 4.70 & 2.35 & 2.50 & 4.10 & $5 \cdot 35$ & 5.57 \\
\hline & 3.02 & 0.98 & 4.65 & 2.33 & 2.45 & 4.07 & $5 \cdot 35$ & $5 \cdot 56$ \\
\hline & 2.98 & 0.98 & $4 \cdot 65$ & 2.31 & 2.44 & 4.03 & $5 \cdot 31$ & $5 \cdot 53$ \\
\hline
\end{tabular}


TABLE III (Continued)

Data pertaining to the analyses of $B$. Coli grown on Media I to VIII

Determinations and calculations are based on Wet Bacteria

\begin{tabular}{|c|c|c|c|c|c|c|c|c|}
\hline & & & & MEDI & & & & \\
\hline & $\begin{array}{c}I \\
\text { Per } \\
\text { Cent. }\end{array}$ & $\begin{array}{c}\text { II } \\
\text { Per } \\
\text { Cent. }\end{array}$ & $\begin{array}{l}\text { III } \\
\text { Per } \\
\text { Cent. }\end{array}$ & $\begin{array}{c}\text { IV } \\
\text { Per } \\
\text { Cent. }\end{array}$ & $\begin{array}{c}V \\
\text { Per } \\
\text { Cent. }\end{array}$ & $\begin{array}{c}\text { VI } \\
\text { Per } \\
\text { Cent. }\end{array}$ & $\begin{array}{c}\text { VII } \\
\text { Per } \\
\text { Cent. }\end{array}$ & $\begin{array}{l}\text { VIII } \\
\text { Per } \\
\text { Cent. }\end{array}$ \\
\hline \multirow{3}{*}{$\begin{array}{l}\text { Protein } \\
\text { (Acid precipitable) }\end{array}$} & $7 \cdot 48$ & 6.65 & 9.60 & $7 \cdot 37$ & 4.67 & 6.53 & 6.90 & 2.14 \\
\hline & 7.45 & 6.62 & $9.5^{6}$ & $7 \cdot 30$ & $4 \cdot 5^{8}$ & 6.49 & 7.01 & 2.09 \\
\hline & $7 \cdot 40$ & $6.5^{8}$ & 9.53 & 7.28 & $4 \cdot 55$ & $6.4 \mathrm{I}$ & 6.89 & 2.03 \\
\hline \multirow{3}{*}{$\begin{array}{l}\text { Protein } \\
\text { (Alkali-precipitable) }\end{array}$} & 5.64 & $7 \cdot 50$ & 2.89 & 6.20 & $5 \cdot 4 \mathrm{I}$ & 6.72 & 6.84 & 4.29 \\
\hline & $5.6 \mathrm{I}$ & $7 \cdot 47$ & 2.83 & 6.01 & $5 \cdot 3^{2}$ & 6.63 & 6.79 & 4.24 \\
\hline & $5 \cdot 5^{8}$ & $7 \cdot 39$ & 2.76 & 6.00 & 5.28 & 6.57 & 6.79 & 4.19 \\
\hline \multirow{3}{*}{$\begin{array}{l}\text { Protein } \\
\text { (Soluble) }\end{array}$} & 0.06 & 2.20 & I. 47 & 0.09 & 0.14 & 0.09 & 1.22 & I. 14 \\
\hline & 0.05 & 2.27 & I. 30 & 0.09 & O.I I & 0.09 & I. $2 \mathrm{I}$ & I. 08 \\
\hline & 0.04 & 3.01 & I. 22 & 0.05 & 0.08 & 0.08 & I. $2 \mathrm{I}$ & 1.07 \\
\hline \multirow{3}{*}{$\begin{array}{l}\text { Protein } \\
\quad \text { (Insoluble) }\end{array}$} & 0.05 & 0.05 & 0.10 & 0.07 & $\mathrm{I} .0 \mathrm{I}$ & 0.08 & 0.13 & 0.04 \\
\hline & 0.05 & 0.03 & 0.08 & 0.05 & 0.98 & 0.06 & 0.09 & 0.02 \\
\hline & 0.05 & 0.03 & 0.08 & 0.03 & 0.98 & 0.06 & 0.09 & 0.02 \\
\hline \multirow{3}{*}{$\begin{array}{l}\text { Residue } \\
\text { (Insoluble) }\end{array}$} & I.03 & 2.40 & 2.05 & I. 43 & 1.76 & 1.00 & 1.52 & $0.8 \mathrm{I}$ \\
\hline & 0.99 & 2.39 & $2.0 \mathrm{I}$ & I. 39 & 1.69 & 0.97 & I. 48 & 0.79 \\
\hline & 0.99 & 2.32 & 2.00 & I.39 & 1.63 & 0.95 & I.43 & 0.75 \\
\hline \multirow[t]{3}{*}{ Fats } & 4.06 & 4.40 & 4.91 & 5.80 & 8.01 & * & * & 5.10 \\
\hline & 4.01 & 4.34 & 4.82 & 5.78 & 8.00 & & & 5.06 \\
\hline & 3.98 & 4.29 & 4.78 & 5.75 & 8.00 & & & 5.05 \\
\hline \multirow[t]{3}{*}{ Carbohydrate } & 4.03 & 3.13 & 2.22 & I. 41 & 2.73 & 3.06 & 2.95 & I.04 \\
\hline & 4.00 & 3.10 & 2.19 & I. 39 & 2.68 & 3.00 & 2.90 & 1.00 \\
\hline & 3.97 & 3.09 & 2.17 & I. 35 & 2.66 & 2.97 & 2.86 & 0.97 \\
\hline \multirow[t]{3}{*}{ Cellalose-like substance } & 1.03 & 2.45 & 2.06 & 1.46 & 1.79 & I.IO & I. 55 & 0.90 \\
\hline & 0.99 & $2.4 \mathrm{I}$ & 2.01 & 1.40 & 1.76 & 1.08 & 1.51 & 0.83 \\
\hline & 0.98 & 2.39 & 1.97 & I. 37 & 1.70 & I.07 & I. 49 & 0.76 \\
\hline
\end{tabular}

* Not determined because of extraneous fat attached to bacteria. 
Differences in quantity of coagulable protein show that the bacterial protein is, in many instances, itself different. This is supported by the fact that the ratio of nitrogen to any one of the protein fractions, or to all of them combined, is not constant. Also, it can be seen that the presence of certain substances in the environment, particularly fats, alters the chemical constitution of the organism.

TABLE IV

Summary of results obtained by use of different media in the cultivation of $B$. Coli

\begin{tabular}{|c|c|c|c|c|c|c|c|c|}
\hline & \multicolumn{8}{|c|}{ MEDIUM } \\
\hline & $\begin{array}{c}I \\
\text { Per } \\
\text { Cent. }\end{array}$ & $\begin{array}{c}\text { II } \\
\text { Per } \\
\text { Cent. }\end{array}$ & $\begin{array}{c}\text { III } \\
\text { Per } \\
\text { Cent. }\end{array}$ & $\begin{array}{c}\text { IV } \\
\text { Per } \\
\text { Cent. }\end{array}$ & $\begin{array}{c}V \\
\text { Per } \\
\text { Cent. }\end{array}$ & $\begin{array}{c}\text { VI } \\
\text { Per } \\
\text { Cent. }\end{array}$ & $\begin{array}{c}V I I \\
\text { Per } \\
\text { Cent. }\end{array}$ & $\begin{array}{c}\text { VIII } \\
\text { Per } \\
\text { Cent. }\end{array}$ \\
\hline Water and Volatile & & & & & & & & \\
\hline Matter & 74.84 & 72.5 & 60.25 & 75.01 & 74.9 & 60.69 & 60.32 & 79.55 \\
\hline Ash & 4.8 & 2.7 & 2.5 & $4 \cdot 5$ & $4 \cdot 5$ & 7.83 & 7.69 & 2.1 \\
\hline Sulphur (Total) & 0.06 & & & 0.1 & 0.09 & & & 0.14 \\
\hline Sulphur (Loose) & & & & 0.02 & o.or & & & 0.03 \\
\hline Phosphorus, $\mathrm{P}_{2} \mathrm{O}_{5}$ & 4.24 & 3.48 & $2.3^{8}$ & 2.89 & $3 \cdot 30$ & 1.69 & I. 83 & 0.92 \\
\hline Calcium, $\mathrm{CaO}$ & 2.66 & 0.05 & 1.06 & 2.62 & 2.60 & 2.34 & 2.34 & 0.19 \\
\hline Nitrogen (Total) & 2.843 & 3.02 & 6.22 & 2.405 & 2.115 & $4 \cdot 327$ & 5.005 & 5.027 \\
\hline Nitrogen (Amino-) & $0.77 \mathrm{I}$ & $0.89 \mathrm{I}$ & 2.970 & 0.724 & $0.69 \mathrm{I}$ & I.696 & 1.650 & 3.012 \\
\hline Protein (Coagulable) & 2.99 & 0.97 & 4.66 & 2.34 & 2.47 & 4.05 & $5 \cdot 32$ & $5 \cdot 54$ \\
\hline $\begin{array}{l}\text { Protein } \\
\text { (Acid-precipitable) }\end{array}$ & $7 \cdot 42$ & $6.6 \mathrm{I}$ & 9.57 & $7 \cdot 32$ & $4.6 I$ & 6.47 & 6.93 & 2.08 \\
\hline $\begin{array}{l}\text { Protein } \\
\text { (Alkali-precipitable) }\end{array}$ & 5.60 & $7 \cdot 44$ & 2.80 & 6.05 & $5 \cdot 33$ & 6.63 & 6.80 & 4.22 \\
\hline $\begin{array}{l}\text { Protein } \\
\text { (Soluble) }\end{array}$ & 0.05 & 2.25 & I.3I & 0.07 & 0.10 & 0.08 & I.2I & I. IO \\
\hline $\begin{array}{l}\text { Protein } \\
\text { (Insoluble) }\end{array}$ & 0.05 & 0.04 & 0.09 & 0.06 & 0.99 & 0.07 & 0.10 & 0.03 \\
\hline $\begin{array}{l}\text { Residue } \\
\quad \text { (Insoluble) }\end{array}$ & 1.00 & 2.37 & 2.00 & 1.40 & 1.70 & 0.98 & I.49 & 0.76 \\
\hline Fats & 3.99 & $4 \cdot 32$ & 4.82 & $5 \cdot 77$ & 8.00 & & & 5.07 \\
\hline Carbohydrate & 4.00 & 3.10 & 2.19 & 1.38 & 2.69 & 3.01 & 2.88 & 1.00 \\
\hline Cellulose-like substance & 1.00 & 2.42 & 2.01 & 1.41 & I.75 & 1.09 & 1.52 & $0.8 \mathrm{I}$ \\
\hline
\end{tabular}

* Not determined because of extraneous fat attached to bacteria. 


\section{BIOLOGICAL VARIATIONS}

As the chemical constituents of the bacterial cell seem to be affected by a change in medium, so does it appear that the biological characteristics alter. Having seen that bacteria vary as stated above in regard to chemical composition when grown on different media, it seemed desirable to determine if such variation was accompanied (as might be reasonably expected) by variations in the biological activities of the organism.

From those biological characteristics that can be definitely measured, we have selected (I) the ability to produce enzymes capable of splitting different carbohydrates with the formation of gas and acid; and (2) the ability to agglutinate with immune rabbit serum prepared with the organism as antigen.

\section{CARBOHYDRATES}

The organism (B. Coli) was grown on the eight different media used above, and after about 200 generations were transplanted directly

TABLE V

Results of B. Coli grown on eight different media and transferred to litmus-carbohydrate-serum-water

'A' indicates hours required to produce marked acidity to litmus. ' $G$ ' indicates hours required for first appearance of gas.

\begin{tabular}{|c|c|c|c|c|c|c|c|c|c|c|c|c|c|c|c|c|}
\hline \multirow{3}{*}{$\begin{array}{c}\text { Carbohy- } \\
\text { drates }\end{array}$} & \multicolumn{16}{|c|}{ MEDIUM } \\
\hline & \multicolumn{2}{|c|}{$I$} & \multicolumn{2}{|c|}{$I I$} & \multicolumn{2}{|c|}{$I I I$} & \multicolumn{2}{|c|}{ IV } & \multicolumn{2}{|c|}{$V$} & \multicolumn{2}{|c|}{$V I$} & \multicolumn{2}{|c|}{$V I I$} & \multicolumn{2}{|c|}{$V I I I$} \\
\hline & $A$ & $G$ & $A$ & $G$ & $A$ & $G$ & & $G$ & $A$ & $G$ & & $G$ & $A$ & $G$ & & $G$ \\
\hline Lactose & 24 & 24 & 24 & 24 & 18 & I8 & 10 & IO & 10 & 10 & 10 & 10 & 10 & 10 & 48 & 48 \\
\hline Mannit & 24 & 24 & 24 & 24 & 24 & 24 & I 8 & I 8 & I8 & 18 & 10 & 10 & 10 & 10 & 48 & 48 \\
\hline Saccharose & 24 & 24 & 36 & 72 & 36 & & 24 & 24 & 24 & 24 & & & & & 48 & 48 \\
\hline Maltose & 24 & 24 & I 8 & 18 & 18 & 18 & 18 & I 8 & 18 & 18 & 18 & I 8 & IO & 10 & 36 & 36 \\
\hline Levulose & 24 & 24 & 24 & 24 & 24 & 24 & 24 & 24 & 12 & 12 & 5 & 5 & 5 & 5 & 48 & 48 \\
\hline Dextrose & 24 & 24 & 24 & 24 & 24 & 24 & 24 & 24 & 24 & 24 & 5 & 5 & 5 & 5 & 36 & 36 \\
\hline Galactose & 24 & 24 & I 8 & 18 & 18 & 18 & 12 & 12 & 12 & 12 & 5 & 5 & 5 & 5 & 40 & 40 \\
\hline Dextrin & & 48 & 36 & 36 & 30 & 30 & 24 & 24 & 30 & 30 & 10 & I0 & 10 & 10 & 56 & 56 \\
\hline
\end{tabular}


in every case to tubes of litmus-carbohydrate-serum-water, in which the production of acid and gas was noted. The time of the appearance of the phenomena in each case is recorded in Table V.

Since the organisms were originally the same, variations observed in the carbohydrate media are referred to changes of the bacteria during growth in the eight media selected. From this Table it is seen that great variations in the enzyme production of bacteria are produced by appropriate changes in the environment. This is evidenced by the widely differing results obtained by the organism after becoming accustomed to different metabolic conditions. The organism from Medium I behaves precisely as a B. Coli Communior, while from Media VI and VII it possesses almost the type characteristics of a B. Coli Communis. Although bacteriologists have been accustomed to regard them as distinct species, we have been able, by the aid of fatty acids in the culture medium, to obtain what practically amounts to a transposition from one to the other.

\section{AGGLUTINABILITY}

In order to test variability, if any, in the agglutinability of the organism after removal from the eight specified environments, sera were prepared from rabbits injected with the organisms grown on Media I, III, V, and VII. The sera were then used in producing agglutination of the organism grown on all the different media. The results are given in Table VI.

TABLE VI

Agglutinated organism (B. Coli) grown on

\begin{tabular}{c|c|c|c|c|c|c|c|c|c}
\hline \hline \multirow{2}{*}{$\begin{array}{c}\text { Agglutinating } \\
\text { organism as } \\
\begin{array}{c}\text { antigen grown } \\
\text { on Medium }\end{array}\end{array}$} & $I$ & $I I$ & $I I I$ & $I V$ & $V$ & $V I$ & $V I I$ & $V I I I$ \\
\cline { 2 - 7 } & & & & & & & & & \\
\hline & 400 & 400 & 400 & 400 & 400 & 400 & 400 & 400 \\
III & 500 & 500 & 800 & 600 & 700 & 400 & 400 & 700 \\
V & 450 & 450 & 630 & 700 & 850 & 700 & 750 & 500 \\
VII & 600 & 600 & 800 & 600 & 800 & 900 & 900 & 700 \\
& & & & & & & & & \\
\end{tabular}


The fact that almost the same agglutination was observed in every case shows by the most conclusive test we know that serologically the organism retained the properties of the Colon bacillus. The organism presents the most active antigenic properties when grown on a medium containing fat, the least when grown without protein. The maximum agglutination generally takes place when the antigenic and agglutinated organisms are grown on the same medium.

This establishes a very definite proof of the constitutional change in the organism. The differences observed in agglutinability are easily as great as those frequently utilized to demonstrate the existence of different 'strains' of the same basic organism.

Since antigenic differences appear to be produced so readily, it seems to us reasonable to suppose that they can be found in all bacteria, and can be referred to the immediate past environment of the organism; further real information they do not disclose. These findings warn us, on the other hand, that bacteria are capable of change; consequently, if the slightly variable strains, frequently kept for investigation in laboratories, remain on the same medium for a long period, they can be expected to lose their differential characteristics, exhibiting only those that are common to all the strains.

Connected with these fundamental changes we have sought evidence of morphological alteration. The organism grown on Medium I showed a bacillus about 2 micra long, in thickness $I / 4$ its length; on Medium III, generally 3 to 5 micra long, almost I micron thick; on Medium VII, 3 to 5 micra long, more than I micron thick. The true significance of these morphological changes must be determined by the variations already noted.

\section{GENERAL CONCLUSIONS}

We have shown that by changing the character of the media upon which a given variety of bacteria is grown, the chemical constitution of the bacteria can be made to vary and, with it, certain biological characteristics such as agglutinability with immune serum and the formation of sugar-splitting enzymes. In some instances the variations practically amount to the 'production' of a new strain. Accompanying morphological changes appear to be relatively unimportant. 


\section{DE VITA AUCTORIS}

Andrew Ignatius Dawson, born on the 25th day of April, in the year 1876 :

After elementary education, and five years' study of theoretical and instrumental music, was admitted to St. Vincent's Apostolic School, Germantown, Pa., in 1897.

Completing studies in department in 1900 , he was entered as resident student of the Congregation of the Mission at St. Vincent's Seminary, Germantown, Pa., attending courses also at The University of Pennsylvania. Having met the requirements of the seminary curriculum, he was ordained Priest on May 25, 1907.

From 1907 to 1912 he held the professorship of Greek at Niagara University, Niagara Falls, N. Y., also continuing the study of chemistry and biology with courses at Harvard University.

In 1912 he was made professor of biology at St. John's College, Brooklyn, N. Y.

In I914 matriculated for the degree of Master of Arts at Columbia University, N. Y., receiving that degree in 1916, submitting the thesis 'The Preparation of Gonococcus Antigen'.

A paper 'Extraction of Fat from Bacteria' was accepted for publication by the Biochemical Bulletin of the Columbia University Biochemical Association. 

Gaylord Bros.

Makers

Syraouse, N. Y.

PAI. 14X. 21, 1908

\section{YC 88573}

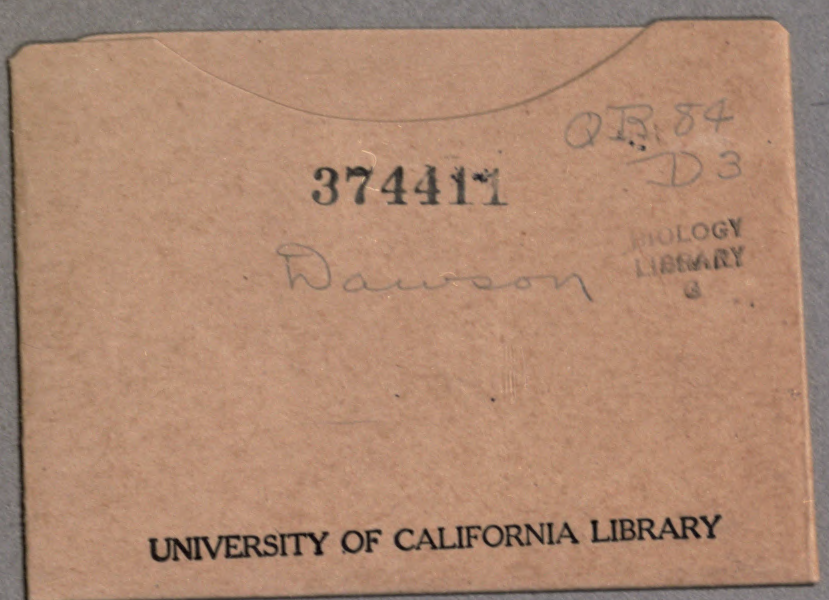


